\title{
Inhibition of cAMP Response Element-Binding Protein or Dynorphin in the Nucleus Accumbens Produces an Antidepressant-Like Effect
}

\author{
Samuel S. Newton, ${ }^{1}$ Johannes Thome, ${ }^{1}$ Tanya L. Wallace, ${ }^{1}$ Yukihikko Shirayama, ${ }^{1}$ Lee Schlesinger, ${ }^{1}$ \\ Norio Sakai, ${ }^{1}$ Jingshan Chen, ${ }^{1}$ Rachael Neve, ${ }^{2}$ Eric J. Nestler, ${ }^{3}$ and Ronald S. Duman ${ }^{1}$ \\ ${ }^{1}$ Division of Molecular Psychiatry, Abraham Ribicoff Research Facilities, Connecticut Mental Health Center, Yale University \\ School of Medicine, New Haven, Connecticut 06508, ${ }^{2}$ McLean Hospital, Harvard University, Belmont, Massachusetts \\ 02478, and ${ }^{3}$ Department of Psychiatry, The University of Texas Southwestern Medical Center, Dallas, Texas 75390
}

The cAMP response element-binding protein (CREB) is a critical integrator of neural plasticity that is responsive in a brain region-specific manner to a variety of environmental and pharmacological stimuli, including widely prescribed antidepressant medications. We developed inducible transgenic lines of mice that express either CREB or a dominant-negative mutant of CREB (mCREB) in forebrain regions and used these mice to determine the functional significance of this transcription factor in the learned helplessness paradigm, a behavioral model of depression. We also use a complementary viral-mediated gene transfer approach to directly test the effect of mCREB in the nucleus accumbens, a brain region important for motivation and reward. The results demonstrate that blockade of CREB by overexpression of $\mathrm{mCREB}$ in transgenic mice or by viral ex-

Despite more than 40 years of clinical use, the molecular and cellular mechanisms underlying the long-term, therapeutic actions of antidepressants remain poorly understood. In recent years, the focus of research has been at a level beyond the serotonin and norepinephrine transporters, the acute targets for the antidepressant reuptake blockers, to the intracellular signal transduction cascades that underlie the regulation of neuronal function (Duman et al., 1997, 2000; Manji et al., 2001b; Nestler et al., 2002). A requirement for adaptations of intracellular signaling pathways, including regulation of transcription factors and gene expression, could account for the time delay of weeks to months in the therapeutic response to antidepressants. Identification of these long-term adaptations has been a major focus of research and could lead to drug targets for the development of fasteracting and more efficacious treatments.

Adaptations of the cAMP signal transduction cascade in response to chronic (14-21 d) but not acute (1-7 d) antidepressant treatment have been reported, suggesting that this secondmessenger system could account for the actions of antidepressants (Duman et al., 2000). These adaptations include upregulation of the function and expression of the cAMP response element-

\footnotetext{
Received Aug. 15, 2002; revised Sept. 27, 2002; accepted Oct. 3, 2002.

This work is supported by United States Public Health Service Grants MH45481 and 2 PO1 MH25642, a Veterans Administration National Center grant for posttraumatic stress disorder, and by the Connecticut Mental Health Center.

Correspondence should be addressed to Ronald S. Duman, Division of Molecular Psychiatry, Abraham Ribicoff Research Facilities, Connecticut Mental Health Center, Yale University School of Medicine, New Haven, CT 06508. E-mail: ronald.duman@yale.edu.

Copyright (C) 2002 Society for Neuroscience $0270-6474 / 02 / 2210883-08 \$ 15.00 / 0$
}

pression of mCREB in the nucleus accumbens produces an antidepressant-like effect, whereas overexpression of CREB in transgenic mice results in the opposite phenotype. In addition, mCREB expression was colocalized with and decreased the expression of prodynorphin in nucleus accumbens medium spiny neurons, and antagonism of dynorphin in the nucleus accumbens was sufficient to produce an antidepressant-like effect similar to that observed after blockade of CREB. Together, the results demonstrate that nucleus accumbens CREB-dynorphin influence behavior in the learned helplessness model and suggest that this signaling cascade may contribute to symptoms of depression.

Key words: learned helplessness; dysphoria; depression; prodynorphin; к-opiate receptors; behavior

binding protein (CREB) in limbic brain regions implicated in mood disorders, including the hippocampus and amygdala (Nibuya et al., 1996; Thome et al., 2000; Blom et al., 2002). CREB is a critical mediator of neural plasticity and has been implicated in learning, memory, and the long-term actions of opiates and psychostimulants, as well as antidepressants (Nestler and Aghajanian, 1997; Milner et al., 1998; Silva et al., 1998). A role for CREB in depression and in mediating the action of antidepressant treatments is supported by several recent studies. First, viral-mediated expression of CREB in the hippocampus produces an antidepressant-like effect in behavioral models of depression (Chen et al., 2001). Second, postmortem studies have demonstrated that levels of CREB in cerebral cortex are decreased in patients with depression and significantly increased when patients were receiving antidepressant treatment at the time of death (Dowlatshahi et al., 1998). Third, drugs that block the metabolism of cAMP and hence increase cAMP function (e.g., rolipram, an inhibitor of cAMP-specific phosphodiesterase type IV) produce antidepressant effects in both animal and clinical studies (Duman et al., 2000). However, there are also reports suggesting that blockade of the cAMP-CREB cascade underlies the actions of antidepressant treatment. Repeated antidepressant administration decreased levels of phosphorylated CREB in frontal cortex (Rossby et al., 1999; Manier et al., 2002), although hippocampus and amygdala were not examined in these studies. In addition, viral-mediated expression of a dominant-negative mutant of CREB (mCREB) in the nucleus accumbens produces an antidepressant-like effect in the forced swim model of depression, whereas expression of CREB in this brain region produces the opposite effect (Pliakas et al., 2001). Finally, null mutation of 
CREB also results in an antidepressant-like effect in the forced swim paradigm (Conti et al., 2002).

To further address this issue, a combination of approaches, including inducible transgenic mice, viral-mediated gene transfer, and microinfusions of a receptor antagonist, were used to examine the role of CREB in the learned helplessness model of depression. The results demonstrate that blockade of CREB or dynorphin (a putative target gene for CREB) in the nucleus accumbens produces an antidepressant effect and, together with previous studies, indicate that CREB can produce different effects in depression models depending on the brain region in which it is expressed.

\section{MATERIALS AND METHODS}

Transgenic mice. To assess the effect of CREB and mCREB on behavior in models of depression, we generated transgenic mice expressing CREB or mCREB under the tetracycline responsive promoter (Furth et al., 1994; Chen et al., 1998). We described recently the expression pattern and neurochemical phenotype of the CREB bitransgenic line of mice used in this study (Sakai et al., 2002); the current paper focuses on characterization of the expression pattern of the mCREB bitransgenic mice and the behavioral phenotype of both mouse lines. The CREB mutant contains a serine-to-alanine substitution at position 133, eliminating the protein kinase A phosphorylation site but maintaining charge balance (Gonzalez and Montminy, 1989). Nonphosphorylated mCREB can still bind to cAMP response elements (CREs) but inhibits CREB action by occupying the CRE and preventing access by wild-type CREB and other CRE-binding proteins (Shaywitz and Greenberg, 1999). A $1.1 \mathrm{~kb}$ fragment of the vector containing mCREB (a gift from Michael E. Greenberg, Harvard Medical School, Boston, MA) was engineered with a FLAG tag peptide (Asp-Tyr-Lys-Asp-Asp-Asp-Asp-Lys) and subcloned into a modified TetOP (tetracycline regulated) promtor construct (Shockett et al., 1995). The new plasmid was designated as pTetOPmCREB. A DNA fragment [containing the promoter, open reading frame, simian virus 40 intron, and poly $\left(\mathrm{A}^{+}\right)$signal] from pTetOPmCREB was purified by electroelution and microinjected into the pronuclei of oocytes from SJL $\times$ C57BL $/ 6$ mice. The mice expressing the tetracycline transactivator (tTA) gene under the control of the neuronspecific enolase (NSE) promoter were generated by our laboratory as described previously (Chen et al., 1998; Kelz et al., 1999; Sakai et al., 2002). Tail DNA from both mice was isolated using Tissue Amp DNA kit (Quiagen, Chatsworth, CA), and analyzed for the transgene by PCR, dot blotting, or Southern blotting (Sambrook et al., 1989). Of these techniques, PCR was used for routine genotyping of the transgenic mice. The founder mice were crossbred with ICR outbred mice to generate F1 mice. F2 homozygous transgenic mice were obtained by crossbreeding F1 siblings; the homozygous genotype was confirmed by crossbreeding them with wild-type mice. We used only one of each single transgenic line for the present study. During the prenatal period to postnatal week 3, the transgenic mice were given doxycycline $(100 \mu \mathrm{g} / \mathrm{ml}$; Sigma, St. Louis, $\mathrm{MO}$ ), an analog of tetracycline, in drinking water to turn off the expression of CREB or mCREB in mice carrying the NSE-tTA gene plus the TetOP-mCREB or TetOP-CREB gene as described previously (Chen et al., 1998). From postnatal week 3 to 10, mice were fed without doxycycline to wash out doxycycline and express the target gene. At postnatal week 10 , single (NSE-tTA ${ }^{+} /$TetOP $\mathrm{CREB}^{-}$or NSE-tTA ${ }^{+} / \mathrm{TetOP}_{-}$ $\mathrm{mCREB}^{-}$) or bitransgenic $\left(\mathrm{NSE}-\mathrm{tTA}^{+} / \mathrm{TetOP}_{-\mathrm{CREB}}{ }^{+}\right.$or NSE$\mathrm{tTA}^{+} / \mathrm{TetOP}^{-\mathrm{mCREB}^{+}}$) mice were used for characterization of the expression pattern or to determine the behavioral phenotype. Animal use procedures were in accordance with the NIH Guide for the Care and Use of Laboratory Animals and were approved by the Yale University Animal Care and Use Committee.

Immunohistochemistry. All mice were killed via intracardial perfusion with $4 \%$ paraformaldehyde under anesthetization with sodium pentobarbital $(100 \mathrm{mg} / \mathrm{kg}$, i.p.). Brains were removed and fixed in paraformaldehyde for an additional $4 \mathrm{hr}$ and then immersed overnight in $20 \%$ glycerol. A freezing microtome was used to collect serial coronal $30 \mu \mathrm{m}$ sections through the entire forebrain. Immunodetection of FLAG-tagged mCREB was performed using free-floating $30 \mu \mathrm{m}$ sections. Sections were incubated in $0.5 \%$ Triton X-100 in TBS for $45 \mathrm{~min}$ at $4^{\circ} \mathrm{C}$, blocked in $5.0 \%$ normal horse serum $-0.1 \%$ Triton $\mathrm{X}-100$ in TBS for $45 \mathrm{~min}$ at $4^{\circ} \mathrm{C}$, and incubated overnight at $4^{\circ} \mathrm{C}$ in mouse monoclonal antibody against
FLAG (1:1000; Sigma). The avidin-biotin blocking kit (Vector Laboratories, Burlingame, CA) was used to reduce nonspecific labeling. Sections were then incubated in biotinylated secondary antibody for $1 \mathrm{hr}$ at room temperature, followed by incubation in a preformed avidin and biotinylated horseradish peroxidase macromolecular complex (ABC reagent; Vector Laboratories). mCREB-positive cells were visualized by DAB staining as per the instructions of the manufacturer (Vector Laboratories).

Combined immunohistochemistry and in situ hybridization. Double immunohistochemistry and in situ hybridization analysis was conducted according to a recently developed protocol (Newton et al., 2002). Briefly, immunohistochemistry was performed as mentioned above with modifications to achieve RNase-free conditions. The avidin-biotin blocking step was replaced by blocking solution of $2.5 \%$ BSA, RNase inhibitor (40 $\mathrm{U} / \mathrm{ml})$ and heparin $(3000 \mathrm{U} / \mathrm{ml})$ in PBS. Overnight primary antibody incubation was in solution containing $1 \%$ Triton X-100, 1\% BSA, heparin, and Superase-in RNase inhibitor (Ambion, Austin, TX) in PBS. After incubation in secondary antibody at room temperature for $1 \mathrm{hr}$, sections were treated with $\mathrm{ABC}$ complex, DAB stained, rinsed in PBS, mounted on "probe-on" slides (Fisher Scientific, Houston, TX), and air dried.

In situ hybridization was performed as per standard protocols. Slide pretreatment steps included incubation in Proteinase $\mathrm{K}(0.5 \mu \mathrm{g} / \mathrm{ml}$ in Tris-EDTA buffer for $10 \mathrm{~min}$ ) and chloroform to facilitate riboprobe penetration. After successful in situ hybridization with ${ }^{35} \mathrm{~S}$-labeled riboprobes, determined by film autoradiography, slides were dipped in nuclear track emulsion (Kodak NTB; Eastman Kodak, Rochester, NY) and stored at $4^{\circ} \mathrm{C}$. Slides were developed based on the observation that $1 \mathrm{~d}$ film exposure corresponds to 1 week in emulsion. Sections were counterstained in cresyl violet and coverslipped with DPX mountant (Fluka, Neu-Ulm, Germany).

Learned helplessness paradigm in mice. In this paradigm, an animal is initially exposed to uncontrollable shock stress. When the animal is later placed in a situation in which shock is controllable (escapable), the animal not only fails to acquire the escape responses but also often makes no efforts to escape the shock at all. This escape deficit is reversed by chronic antidepressant treatment (Willner, 1984; Thiébot et al., 1992; Chen et al., 2001). Learned helplessness behavioral tests were performed with the Gemini Avoidance System (San Diego Instruments, San Diego, CA). This apparatus is divided into two equal compartments by a retractable door.

Mice were subjected to 120 inescapable electric footshocks (IES) $(0.45$ $\mathrm{mA}, 15 \mathrm{sec}$ duration, average interval of $45 \mathrm{sec}$ ) in one of the two closed compartments. One day later, a two-way conditioned avoidance test was performed. This test session consisted of 30 trials in which electric footshock [ $0.45 \mathrm{~mA}, 24 \mathrm{sec}$ duration, at random intervals (mean of $30 \mathrm{sec}$, averaging $22-38 \mathrm{sec}$ )] was preceded by a $3 \mathrm{sec}$ conditioned stimulus tone that remained on until the shock was terminated. The Gemini Avoidance System recorded the numbers of escape failures and latencies.

Surgical microinfusions of viral vectors or dynorphin antagonists and learned helplessness in rats. Male Sprague Dawley rats (225-300 gm, Charles River Laboratories, Wilmington, MA) were used. The animals were housed under $12 \mathrm{hr}$ light/dark cycle with access to food and water ad libitum. Surgery was performed in a stereotaxic apparatus (David Kopf Instruments, Tujunga, CA) under anesthesia with pentobarbital sodium solution $(50 \mathrm{mg} / \mathrm{kg}$, i.p.; Abbott Laboratories, North Chicago, IL). For viral-mediated expression studies, infusions of herpes simplex virus (HSV)-LacZ (control) and HSV-mCREB were made into the nucleus accumbens using a standard protocol (Carlezon et al., 1998; Chen et al., 2001). Infusions of $0.5 \mu \mathrm{l}$ of HSV-LacZ or HSV-mCREB were made bilaterally into the nucleus accumbens. The coordinates for the nucleus accumbens (relative to bregma according to the atlas of Paxinos and Watson, 1997) were as follows: $2.0 \mathrm{~mm}$ anteroposterior (AP), \pm 1.6 mediolateral (ML), and -7.2 dorsoventral (DV) from the skull. The infusions were made over a total of $15 \mathrm{~min}$, and, after an additional $5 \mathrm{~min}$ wait period, the injection syringe was removed. Three days later, when HSV-mediated viral expression is maximal (Carlezon et al., 1998; Chen et al., 2001), rats were placed in the learned helplessness chamber and received 90 inescapable shocks $(0.8 \mathrm{~mA}, 15 \mathrm{sec}$ duration) preceded by a $1 \mathrm{sec}$ conditioned stimulus tone over a $90 \mathrm{~min}$ period. The animals were then returned to their home cages and tested in the active avoidance chambers the next day. This test session consisted of 30 trials in which electric footshock [ $0.8 \mathrm{~mA}, 30 \mathrm{sec}$ duration, at random intervals (mean of $30 \mathrm{sec}$, averaging $26-34 \mathrm{sec}$ )] was preceded by a $3 \mathrm{sec}$ conditioned stimulus tone that remained on until the shock was terminated. The numbers of escape failures and escape latencies in each of the 30 

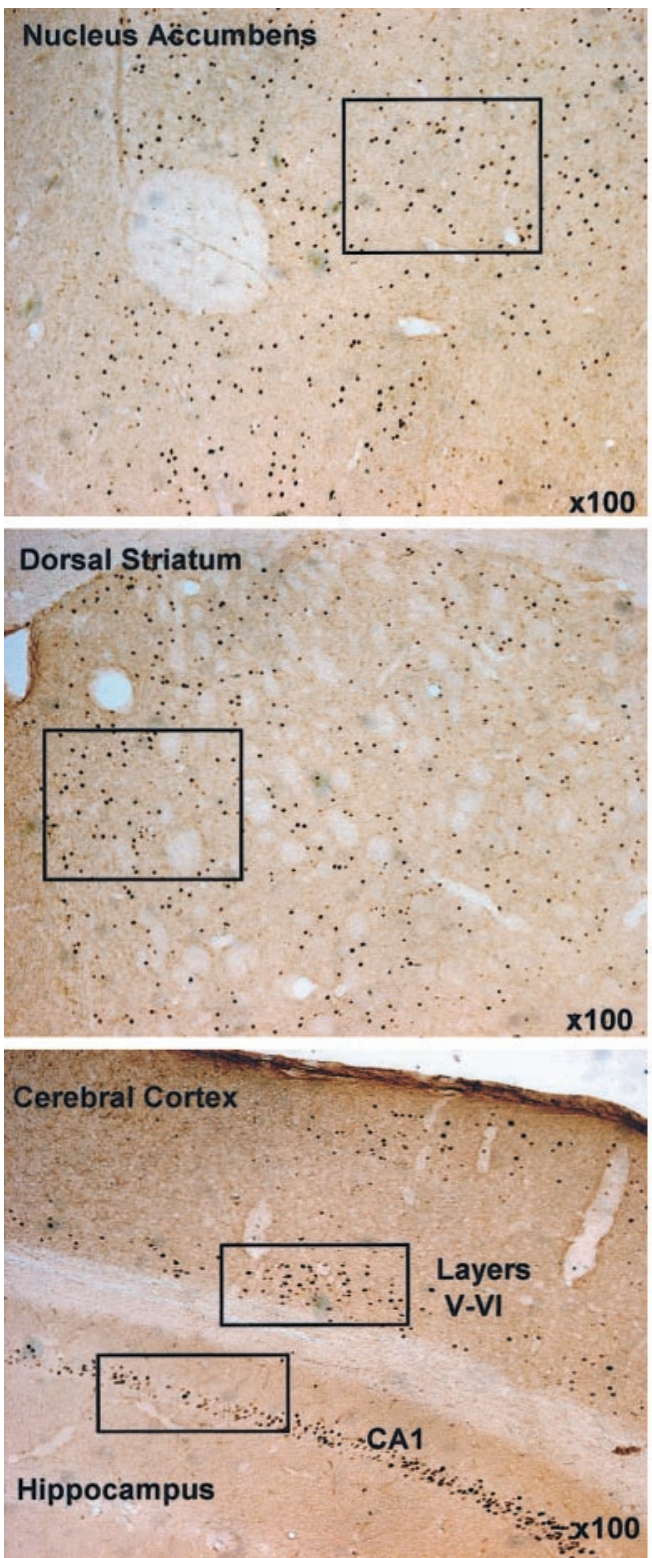
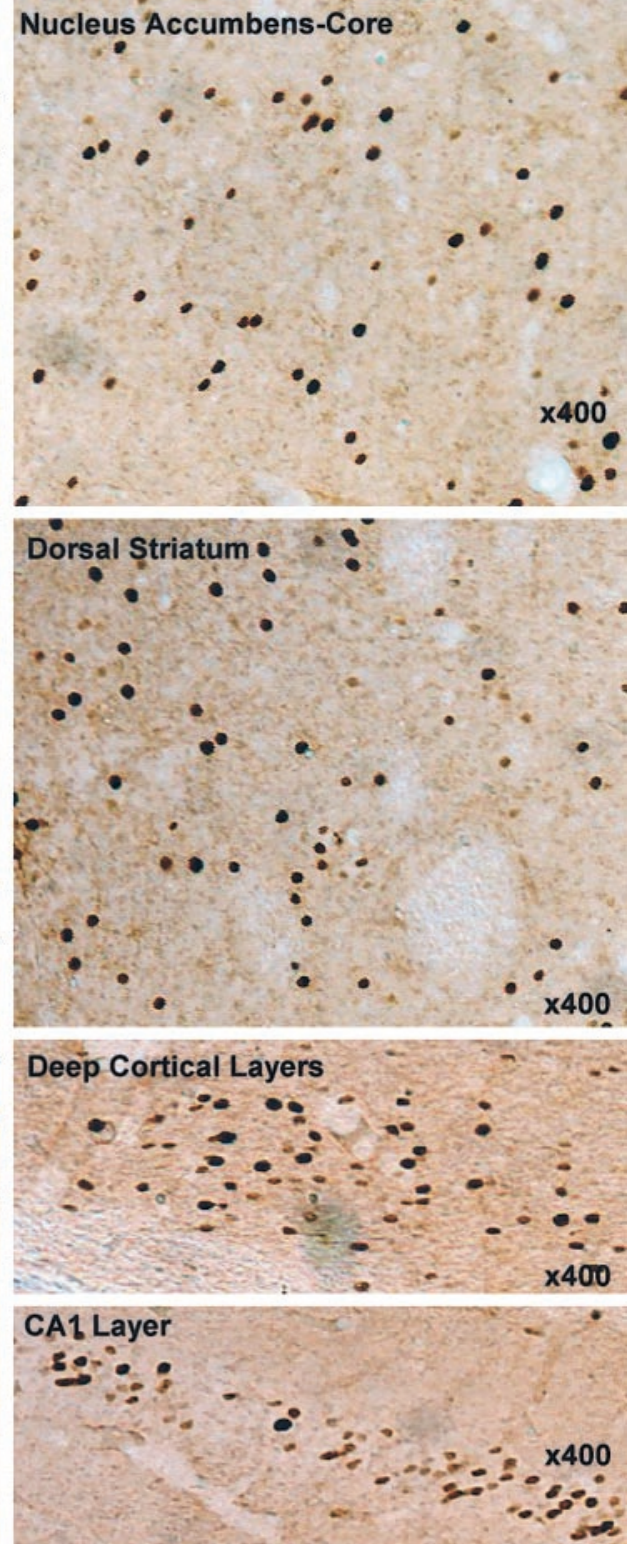

Figure 1. Pattern of FLAG-mCREB overexpression in the forebrain of bitransgenic mice. FLAG-mCREB expression was determined by immunohistochemistry in bitransgenic $\left(\mathrm{tTA}^{+} / \mathrm{mCREB}^{+}\right)$ mice. Doxycycline was administered to bitransgenic mice until weaning, and brains were harvested at 10 weeks of age for immunohistochemical analysis of FLAG-mCREB. In bitransgenic mice, intense staining of FLAG-mCREB is observed in many cells throughout the striatum, particularly the dorsal and medial aspects, and in the nucleus accumbens. A cross section at the level of the dorsal hippocampus also demonstrates FLAGmCREB staining in deep layers of cerebral cortex and in the CA1 pyramidal cell layers. Higher magnification demonstrates that FLAG-mCREB is localized in the nucleus. Results are representative of the analysis of at least three animals in each group. No FLAG-mCREB was observed in wild-type or single transgenic $\left(\mathrm{tTA}^{+} /\right.$ mCREB $^{-}$) mice (data not shown). trials were recorded by the Gemini Avoidance System. After the behavioral tests, the rats were killed by decapitation.

For the dynorphin antagonist studies, rats received bilateral injections of nor-binaltorphimine dihydrochloride (norBNI) or saline $(0.9 \%)$ into one of three different sites: the lateral ventricle, the nucleus accumbens, or the hippocampus. For the lateral ventricle infusions, norBNI (2.5 $\mu \mathrm{g} / \mathrm{side}$ ) was infused in a total volume of $1.0 \mu \mathrm{l}$ into each side over 15 $\mathrm{min}$, and the injection syringe was left in place for an additional $5 \mathrm{~min}$ to allow for diffusion and to prevent flow up the syringe track. The coordinates for the lateral ventricle (relative to bregma according to the atlas of Paxinos and Watson, 1997) were as follows: $-0.3 \mathrm{~mm} \mathrm{AP,} \pm 1.2 \mathrm{ML}$, and $-3.1 \mathrm{DV}$ from the skull. For the nucleus accumbens and the hippocampus, norBNI $(1.0 \mu \mathrm{g} / \mathrm{side})$ was infused in a total volume of 0.5 $\mu \mathrm{l}$ into each side over $15 \mathrm{~min}$, and the injection syringe was left in place for an additional $5 \mathrm{~min}$. The injection syringe was angled at $10^{\circ}$ from the midline for the nucleus accumbens and the coordinates were as follows: $1.7 \mathrm{~mm} \mathrm{AP}, \pm 3.9 \mathrm{ML}$, and $-6.5 \mathrm{DV}$ from the skull. The coordinates for the hippocampus were $-3.8 \mathrm{~mm} \mathrm{AP}, \pm 2.0 \mathrm{ML}$, and $-6.5 \mathrm{DV}$. Learned helplessness was conducted as described above for the viral infusion studies.

Statistical analysis. Statistical differences among more than three groups were estimated by a one-way ANOVA, followed by the Scheffe's test. For comparison of the mean values between the two groups, statistical evaluation was done using the two-tailed Student's $t$ test.

\section{RESULTS}

\section{Pattern of transgene expression in mCREB bitransgenic mice}

To investigate the role of CREB in behavioral models of depression, we developed inducible and brain region-specific transgenic mice using the tetracycline-regulated system (Furth et al., 1994) as described previously by our group (Chen et al., 1998; Kelz et al., 1999; Sakai et al., 2002). An NSE promoter was used to drive expression of the tTA, and the TetOp promoter was used to drive expression of either FLAG-tagged mCREB or wild-type CREB. Single transgenic mice expressing one of the transgenes (e.g., $\left.\mathrm{tTA}^{+} / \mathrm{mCREB}^{-}\right)$or bitransgenic mice expressing both genes $\left(\mathrm{tTA}^{+} / \mathrm{mCREB}^{+}\right)$were raised on doxycycline to repress tTA expression until weaning. Doxycycline was then removed from the water for 6-8 weeks to allow for washout and transgene expression before analysis.

Transgene expression in the mCREB and CREB bitransgenic mice was observed in several forebrain regions in a pattern similar 
mCREB mice
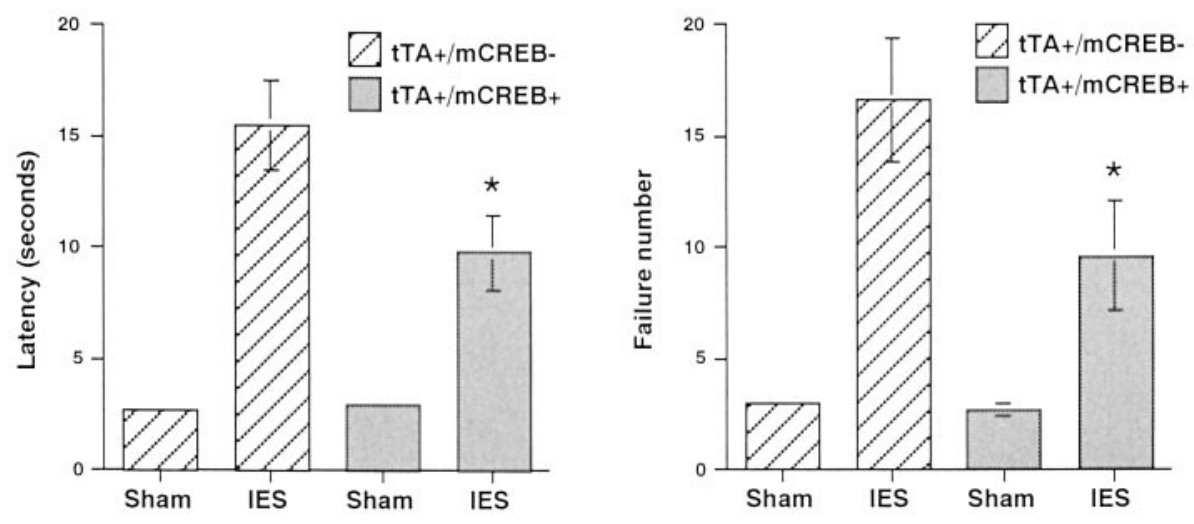

Transgenic expression of mCREB or CREB produces opposite effects in the learned helplessness model of depression. Single $\left(\mathrm{tTA}^{+} /\right.$ $\mathrm{mCREB}^{-}$or $\left.\mathrm{tTA}^{+} / \mathrm{CREB}^{-}\right)$or bitransgenic $\left(\mathrm{tTA}^{+} / \mathrm{mCREB}^{+}\right.$or $\left.\mathrm{tTA}^{+} / \mathrm{CREB}^{+}\right)$mice were exposed to sham treatment or IES and subsequently tested in an active avoidance paradigm (30 trials of $30 \mathrm{sec}$ duration). The results demonstrate that there is a significant reduction in the number of escape failures and the latency to escape in the mCREB bitransgenic mice and that the opposite phenotype is observed in the CREB bitransgenic mice. There was no difference in escape failures or latency between the shamtreated single or bitransgenic animals, indicating that the alteration in active avoidance behavior is a specific response to IES exposure. The results are presented as the mean \pm SEM for each group ( $n=8-15$ per group). * $p<0.05$ compared with single transgenic mice (ANOVA and Fisher's post hoc test).

\section{CREB mice}

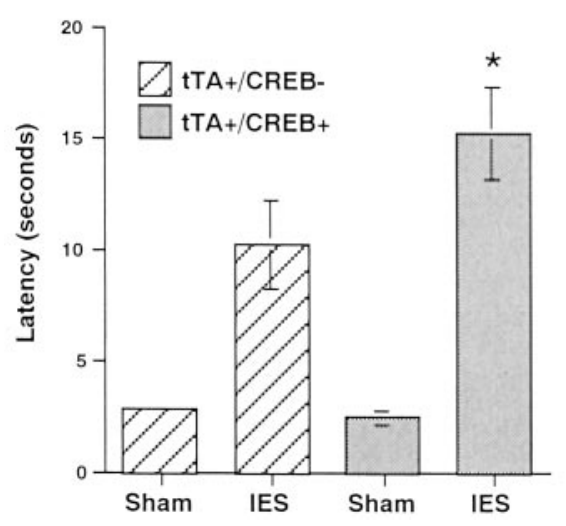

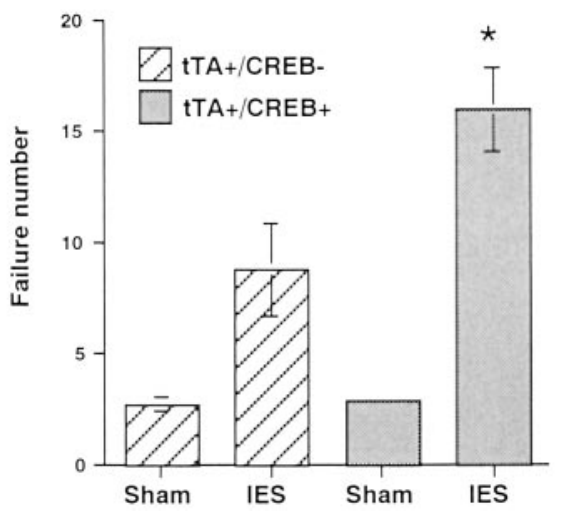

to that observed in other NSE-tTA-regulated mice characterized by our group (Fig. 1) (Chen et al., 1998; Kelz et al., 1999). We characterized recently the expression pattern of the CREB bitransgenic mice (Sakai et al., 2002). Relatively high levels of FLAG-mCREB expression were observed in the striatum, including both the dorsal striatum and the nucleus accumbens, and in certain aspects of cerebral cortex and subfields of hippocampus (Fig. 1). FLAG-mCREB was observed predominantly in the medial portion of dorsal striatum and primarily the core subdivision of the nucleus accumbens, although expression of FLAG-mCREB was observed in other aspects of these regions. High-power magnification demonstrates that FLAG-mCREB expression is restricted to the cell nucleus as would be expected for a transcription factor (Fig. 1; see Fig. 4). FLAG-mCREB was sparsely expressed in the deep and superficial layers of parietal cortex (Fig. 1). Moderate levels of FLAG-mCREB expression were also observed in subregions of the hippocampus, including the CA1 pyramidal cell layer (Fig. 1) and the dentate gyrus granule cell layer (data not shown). In contrast, there was no expression of FLAG-mCREB observed in the single transgenic mice expressing either NSE-tTA only $\left(\mathrm{tTA}^{+} / \mathrm{mCREB}^{-}\right)$or TetOp-mCREB alone $\left(\mathrm{tTA}^{-} / \mathrm{mCREB}^{+}\right)$(data not shown), the latter demonstrating that there was no "leak" expression of the TetOp-mCREB gene. In addition, when animals are maintained on doxycycline, there is no expression of FLAG-mCREB in the bitransgenic mice (data not shown). A similar pattern of transgene expression and regulation by doxycycline has been demonstrated in the CREB bitransgenic mice (Sakai et al., 2002).

\section{Influence of mCREB and CREB on behavior in the learned helplessness model of depression}

The influence of mCREB and CREB in the bitransgenic mice on depression-like behavior was assessed using the learned helplessness model of depression. In this paradigm, exposure to an inescapable, aversive stimulus disrupts the ability of an animal to learn to escape a subsequent noxious stimulus. This deficit is observed in a large number of animal species, including mice, rats, and humans (Seligman and Beagley, 1975). Although it is difficult to access the clinical relevance of animal models of complex behavioral disorders, inescapable stress leads to many physiological and behavioral abnormalities that are observed in depression, and many of these effects are reversed by antidepressant treatment (Shanks and Anisman, 1989; Thiébot et al., 1992; Caldarone et al., 2000).

Single or bitransgenic mCREB or CREB transgenic mice were exposed to IES and then analyzed for escape deficits in an active avoidance test. In both the single transgenic and bitransgenic mCREB or CREB mice, exposure to IES resulted in a significant increase in the number of escape failures and latency to escape relative to sham-treated control animals that were exposed to the shuttle box chambers but did not receive IES (Fig. 2). Moreover, IES resulted in a significant difference between the single and bitransgenic animals, and the effect was opposite in the mCREB versus the CREB bitransgenic animals. In the mCREB bitransgenic mice $\left(\mathrm{tTA}^{+} / \mathrm{mCREB}^{+}\right)$, there was a significant decrease in the number of escape failures and the latency to escape, or an antidepressant-like 

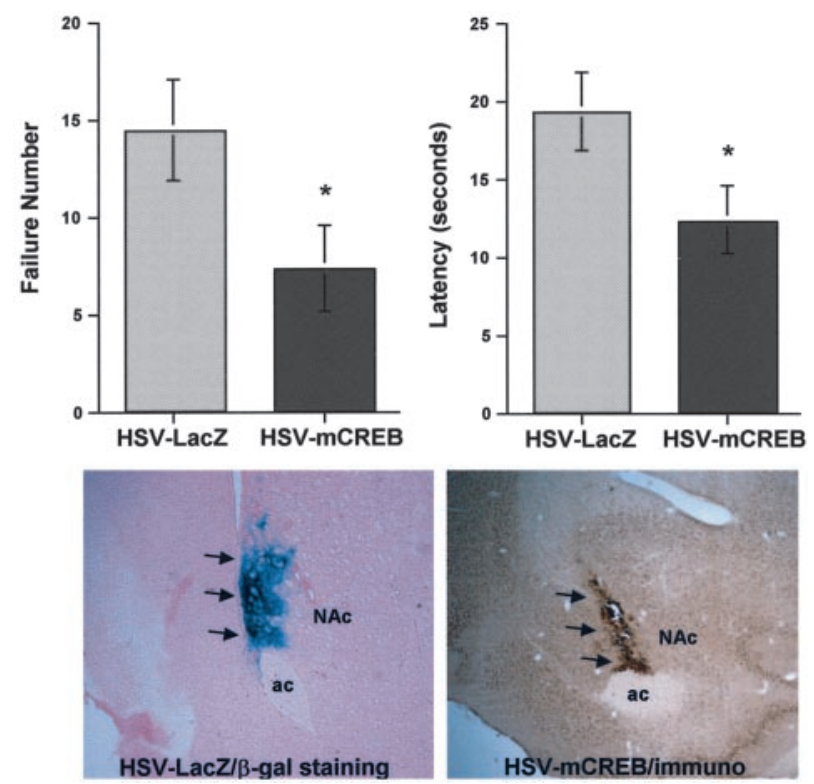

Figure 3. Viral-mediated expression of mCREB in the nucleus accumbens produces an antidepressant-like effect in the learned helplessness paradigm. HSV-LacZ (control) or HSV-mCREB was infused into the nucleus accumbens of rats as described in Materials and Methods. Three days later, when levels of viral expression are maximal, rats were exposed to IES and subsequently tested in an active avoidance paradigm (30 trials, $30 \mathrm{sec}$ duration). Rats receiving intra-accumbens infusions of HSV-mCREB displayed a significant decrease in the number of escape failures and latency to escape. The results are expressed as the mean \pm SEM ( $n=10$ animals per group). ${ }^{*} p<0.05$ compared with HSV-LacZ controls (Student's $t$ test). NAc, Nucleus accumbens; $a c$, anterior commissure; $\beta$-gal; $\beta$-galactosidase.

effect, relative to single transgenic controls $\left(\mathrm{tTA}^{+} / \mathrm{mCREB}^{-}\right)$. In contrast, in CREB bitransgenic mice $\left(\mathrm{tTA}^{+} / \mathrm{CREB}^{+}\right)$, there was a significant increase in the number of failures and latency to escape, a depression-like effect, relative to single transgenic controls (tTA ${ }^{+} / \mathrm{CREB}^{-}$) (Fig. 2).

Although exposure to IES resulted in significant effects in the active avoidance test, there was no difference between single and bitransgenic animals exposed to sham treatment (Fig. 2). In all cases, the number of escape failures and escape latencies in sham-treated animals were comparable in the single and bitransgenic mCREB and CREB mice. This indicates that there was no generalized effect on escape behavior that could underlie the differences that are induced by exposure to IES between the single and bitransgenic CREB and mCREB mice.

To determine whether transgene expression in the nucleus accumbens, a region known to regulate motivation and reward, could account for the behavioral phenotype of the transgenic mice, we used a viral expression approach. Stereotaxic microinfusions of HSV-mCREB or HSV-LacZ (control) were made into the nucleus accumbens according to standard procedures as described previously (Carlezon et al., 1998; Chen et al., 2001). Rats were used for these studies to increase the accuracy of the microinfusions. These viral microinf usions result in mCREB or LacZ expression in a circumscribed region of the nucleus accumbens (Fig. 3) (Carlezon et al., 1998). Infusion of HSVmCREB significantly decreased the number of escape failures and the latency to escape relative to infusions of HSV-LacZ (Fig. 3).
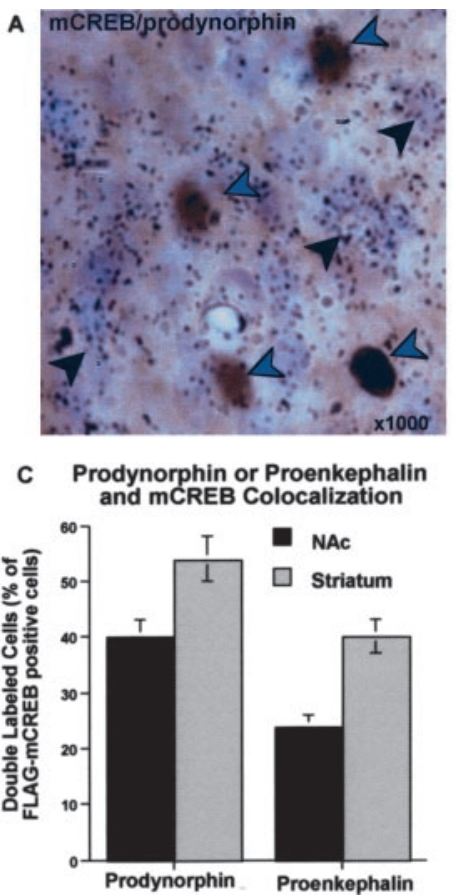

Figure 4. FLAG-mCREB in bitransgenic mice is colocalized with prodynorphin- and proenkephalin-positive neurons in the striatum. FLAG-mCREB immunohistochemistry was combined with ${ }^{35} \mathrm{~S}$ prodynorphin or ${ }^{35} \mathrm{~S}$-proenkephalin in situ hybridization to characterize the subpopulations of neurons that express mCREB. Emulsion grains for both prodynorphin and proenkephalin were localized in the FLAGmCREB immunoperoxidase-stained cells in the nucleus accumbens $(A$, $B$ ) and dorsal striatum (data not shown). The total number of FLAGmCREB cells that were positive for either prodynorphin or proenkephalin were counted (331 and 502 for prodynorphin or proenkephalin, in 3 or 4 animals, respectively). The percentage \pm SEM of FLAG-mCREB and double-labeled prodynorphin or proenkephalin cells is shown in $C$. The level of prodynorphin expression in the FLAG-mCREB-immunopositive cells was also determined. The number of ${ }^{35} \mathrm{~S}$-prodynorphin emulsion grains over FLAG-mCREB-positive cells or adjacent FLAG-mCREBnegative cells in the same sections (50 of each, from 3 different animals) was determined. The results $(D)$ are presented as percentage of control and are the mean \pm SEM. ${ }^{*} p<0.05$ compared with mCREB-negative controls (Student's $t$ test). $N A c$, Nucleus accumbens.

\section{Prodynorphin is colocalized with and regulated by $\mathrm{MCREB}$}

To examine the neurobiological mechanisms underlying the actions of mCREB in the nucleus accumbens, the localization of this transgene in subsets of dynorphin- and enkephalin-positive neurons in this brain region was determined. Colocalization studies were conducted by immunoperoxidase staining for FLAG-mCREB combined with in situ hybridization using ${ }^{35} \mathrm{~S}$ labeled riboprobes for prodynorphin or proenkephalin mRNA as described previously (Kelz et al., 1999; Nakagawa et al., 2002). For quantitative analysis, FLAG-mCREB-immunopositive cells from bitransgenic animals were identified, and the number of cells that express prodynorphin or proenkephalin in the striatum and nucleus accumbens were counted. A total of 331 and 502 FLAGmCREB cells were counted for colocalization with prodynorphin or proenkephalin, respectively ( $n=3$ or 4 animals, respectively). FLAG-mCREB-positive cells in both subfields of the striatum were found to express prodynorphin mRNA, with $\sim 40 \%$ of the cells in the nucleus accumbens and $55 \%$ in the dorsal striatum being double labeled (Fig. 4). FLAG-mCREB-positive cells were 
also found to express proenkephalin mRNA, although the percentage of cells was lower than for prodynorphin-labeled cells. Approximately $25 \%$ of the cells in the nucleus accumbens and $40 \%$ in the striatum were double labeled for FLAG-mCREB and proenkephalin mRNA.

Studies in cultured cells and in brain demonstrate that the expression of prodynorphin is increased by activation of the CAMPCREB cascade and three cAMP response elements in the dynorphin gene promoter (Collins-Hicok et al., 1994; Cole et al., 1995; Carlezon et al., 1998; Sakai et al., 2002). In the present study, the influence of $\mathrm{mCREB}$ expression on prodynorphin mRNA was analyzed to determine whether mCREB produces an effect opposite to that of CREB. The numbers of prodynorphin emulsion grains over either FLAG-mCREB-positive cells or adjacent cresyl violet stained/FLAG-mCREB-negative cells (control) in the same sections were determined (Fig. 4). A total of 50 FLAG-mCREB and 50 control cells were counted in each of three animals (total of 150 cells for each). The results demonstrate that levels of prodynorphin expression are significantly decreased by $>30 \%$ in the FLAG-mCREB-positive cells relative to adjacent control cells not expressing mCREB.

\section{Inhibition of dynorphin in nucleus accumbens produces an antidepressant effect}

Decreased expression of prodynorphin mRNA in the mCREB bitransgenic mice raises the possibility that downregulation of this neuropeptide underlies the behavioral phenotype observed in the mCREB mice. To directly test this hypothesis, the influence of a direct-acting dynorphin receptor antagonist on behavior in the learned helplessness paradigm was determined. The antagonist used for these studies was norBNI, an irreversible, longlasting, and selective antagonist of the dynorphin- $\kappa$-opioid receptor relative to the $\mu$ - and $\delta$-opiate receptor subtypes (Spanagel and Shippenberg, 1993). Once again, rats were used to increase the accuracy of the surgical microinfusions of norBNI into specific brain regions. Bilateral infusions of norBNI into the lateral ventricles produced a significant decrease in the number of escape failures and the latency to escape (Fig. 5), an effect similar to that observed in the bitransgenic mCREB mice and similar to the effect of HSV-mCREB inf usions. Moreover, bilateral microinfusions of norBNI directly into the nucleus accumbens resulted in a similar decrease in the number of escape failures and latency to escape, indicating that blockade of dynorphin in this brain region is sufficient to produce an antidepressant effect. In contrast, bilateral microinfusions of norBNI into the dentate gyrus of the hippocampus did not significantly influence failure number or escape latency, further demonstrating the regional specificity of the effect of norBNI (Fig. 5).

\section{DISCUSSION}

This study uses a combination of approaches to investigate the role of CREB in the learned helplessness model of depression. Results from the inducible CREB and mCREB bitransgenic mice demonstrate that inhibition of CREB produces an antidepressantlike effect. Although the expression pattern is limited in the bitransgenic mice, complementary viral-mediated gene expression studies were used to demonstrate that inhibition of CREB in the nucleus accumbens is sufficient to replicate the effect observed in the mCREB bitransgenic mice. Finally, direct infusions of a $\kappa$-opioid receptor antagonist produced an antidepressant-like effect, indicating that downregulation of prodynorphin expression
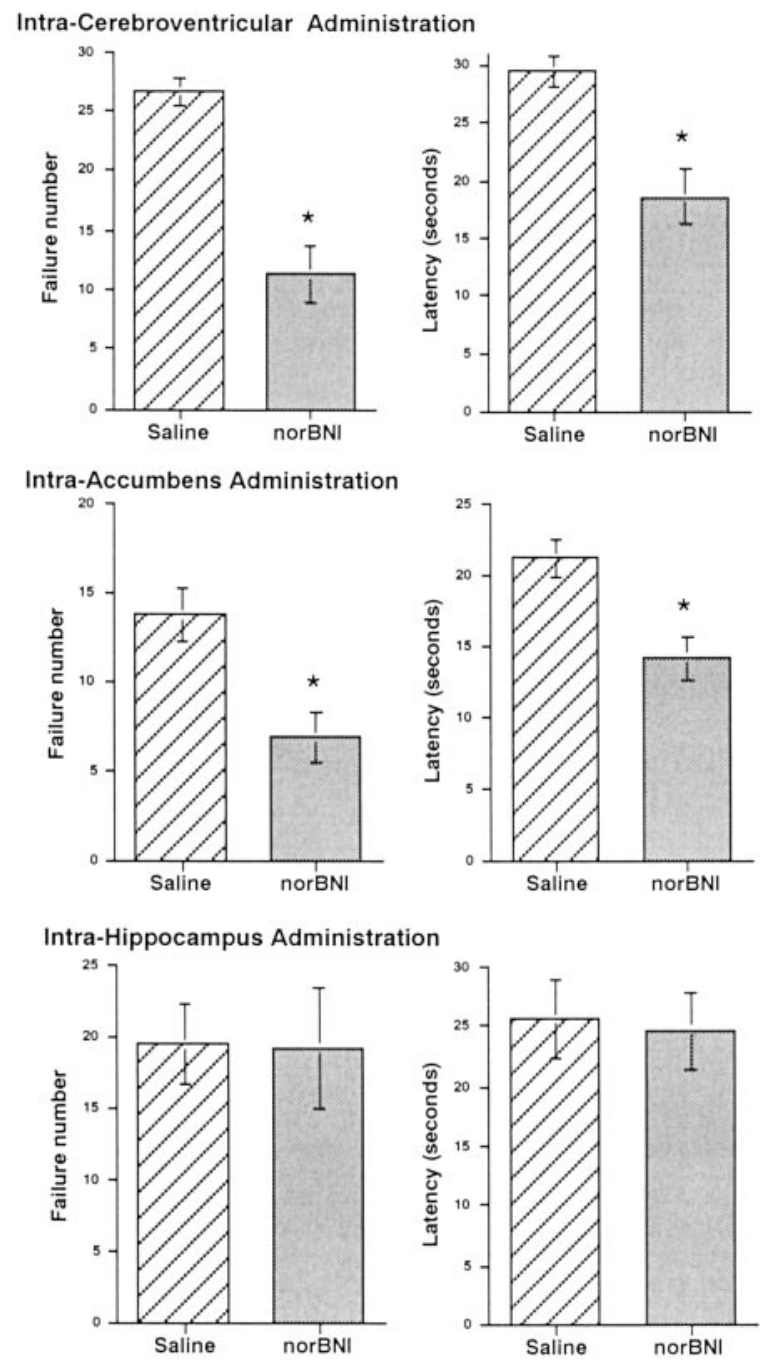

Figure 5. Antagonism of dynorphin- $\kappa$-opioid receptors produces an antidepressant-like effect in the learned helplessness paradigm. Rats were exposed to IES as described in Materials and Methods. One day later, the $\kappa$-opioid receptor antagonist norBNI was microinfused into the lateral ventricles, the nucleus accumbens, or the dentate gyrus of the dorsal hippocampus, and, $3 \mathrm{~d}$ later, the animals were tested in an active avoidance paradigm (30 trials, $30 \mathrm{sec}$ duration). The results demonstrate that intracerebroventricular or intra-accumbens, but not intrahippocampal, microinfusions of norBNI significantly decrease the number of escape failures and the latency to escape. The results are expressed as means \pm SEM $(n=8-10$ animals per group for intracerebroventricular and intraaccumbens infusions; $n=4$ for intrahippocampus infusions). ${ }^{*} p<0.05$ compared with saline controls (Student's $t$ test).

in the mCREB bitransgenic mice could account for the behavioral phenotype in these animals.

In this study, we characterized the expression pattern of mCREB in a new inducible bitransgenic mouse in which transgene expression is under the control of the NSE promoter. Immunohistochemical analysis demonstrates the expression of FLAG-mCREB in several forebrain regions, including the dorsal striatum and nucleus accumbens, as well as in deep layers of cerebral cortex and subfields of hippocampus. This pattern of expression is similar to the expression in other lines of conditional bitransgenic mice under the control of the NSE promoter, including those expressing CREB (Sakai et al., 2002) or $\Delta$ FosB (Kelz et al., 1999). This limited and discrete pattern of expression pro- 
vides a useful approach for studying the function of a transgene in specific brain regions that cannot be achieved with constitutive transgenic mice. In addition, the ability to turn gene expression on after weaning reduces the chance for adaptive responses to transgene expression also encountered in constitutive transgenic lines of mice.

Previous studies have implicated CREB in the actions of antidepressant treatments (see introductory remarks). Such a role for CREB was tested in the present study by analyzing the phenotype of the CREB and mCREB bitransgenic mice in the learned helplessness model of depression. In these studies, overexpression of CREB increased the number of escape failures and latency to escape, effects that are interpreted as a more depressive phenotype. In contrast, overexpression of mCREB produced the opposite effect on failure number and escape latency or an antidepressantlike effect. In sham-treated mice (i.e., not exposed to inescapable shock), there was no difference in active avoidance behavior, indicating that the differences observed in both CREB and mCREB bitransgenic lines develop in response to exposure to inescapable stress and not altered training in the active avoidance test per se.

These results in the learned helplessness studies are surprising based on our previous reports that antidepressant treatment upregulates the CAMP-CREB cascade in the hippocampus, amygdala, and cerebral cortex (Nibuya et al., 1996; Thome et al., 2000). In addition, we reported that viral-mediated expression of CREB in the hippocampus produces an antidepressant-like effect in the learned helplessness and the forced swim paradigms (Chen et al., 2001). Postmortem studies demonstrating that levels of CREB are decreased in cerebral cortex of depressed patients and upregulated in patients receiving antidepressant medication also support the hypothesis that activation of the cAMP-CREB cascade is associated with an antidepressant response (Dowlatshahi et al., 1998). Based on these findings and the expression patterns in the transgenic mice, we hypothesized that the behavioral effects observed could be attributable to expression in striatum, particularly the nucleus accumbens. To test this hypothesis, we used a viralmediated gene transfer approach to express $\mathrm{mCREB}$ in the nucleus accumbens. Microinfusions of HSV-mCREB into the nucleus accumbens decreased the number of escape failures and latency to escape, effects similar to those observed in the mCREB bitransgenic mice. Because viral-mediated gene transfer results in the expression of $\mathrm{mCREB}$ in a specific and circumscribed region of the nucleus accumbens, the results indicate that the behavioral effects of HSV-mCREB, as well as the effects in the mCREB bitransgenic mice, are mediated by actions in the nucleus accumbens. This finding is in agreement with a recent report demonstrating that HSV-mediated mCREB expression in the nucleus accumbens produces a similar antidepressant-like effect in the forced swim model of depression (Pliakas et al., 2001). Similar results were observed using the forced swim test in constitutive CREB partial null mutant mice, although the brain regions underlying this effect were not examined (Conti et al., 2002). Together, the results demonstrate that the influence of CREB in behavioral models of depression is brain region specific, which is not unexpected given the widespread distribution of this transcription factor in different brain regions and cell types.

The ability of CREB to exert opposite effects in the learned helplessness paradigm depending on the brain region in which it is expressed could result from regulation of different target genes in these regions. One potential target gene in the hippocampus is brain-derived neurotrophic factor, which is induced by activation of the cAMP-CREB cascade and is sufficient to produce an antidepressant effect when infused into the hippocampus (Shaywitz and Greenberg, 1999; Shirayama et al., 2002). In the nucleus accumbens, as well as dorsal striatum, the prodynorphin and proenkephalin genes have been identified as targets of CREB (Borsok et al., 1994; Cole et al., 1995; Carlezon et al., 1998), and these neuropeptides define different subpopulations of projection neurons (Gerfen and Young, 1988; Curran and Watson, 1995). Prodynorphin is expressed in the direct projection, and proenkephalin is expressed in the indirect projection, medium spiny neurons. Colocalization studies of the mCREB bitransgenic mice demonstrate that mCREB is expressed in both dynorphin- and enkephalin-positive neurons in the nucleus accumbens, as well as dorsal striatum, with a higher percentage of mCREB-positive cells expressing dynorphin relative to enkephalin. In addition, the levels of prodynorphin mRNA expression are significantly decreased in cells expressing $\mathrm{mCREB}$, demonstrating a functional inhibition of endogenous CREB by the dominant-negative mutant. In the CREB bitransgenic mice, we reported that induction of prodynorphin and CREB-mediated gene transcription is increased (Sakai et al., 2002).

These findings suggest that downregulation of prodynorphin gene expression could contribute to the behavioral phenotype observed in mCREB bitransgenic mice and in response to viral expression of $\mathrm{mCREB}$ in the nucleus accumbens. This possibility is supported by studies demonstrating that infusion of a $\kappa$-opioid receptor antagonist, norBNI, produced an antidepressant-like effect similar to that observed in the mCREB bitransgenic mice and in response to infusion of HSV-mCREB (i.e., decreased number of escape failures and latency to escape). The antidepressant effect of norBNI is observed after infusions into the nucleus accumbens or lateral ventricle but not into the dentate gyrus of the hippocampus, indicating that the effect of the antagonist is mediated by the nucleus accumbens. This finding is consistent with, and extends, the results of a recent study demonstrating that infusion of norBNI into the lateral ventricle produces an antidepressant-like effect in the forced swim test (Pliakas et al., 2001). As discussed by Pliakas et al. (2001), the neurobiological mechanisms underlying the actions of CREB and dynorphin could be related to the regulation of dysphoria by dynorphin in the mesolimbic dopamine system. Dynorphin agonists induce a state of dysphoria in humans, and upregulation of dynorphin is proposed to mediate some of the negative emotional symptoms (which in some patients resemble depression) that occur during cocaine withdrawal. Dynorphin-mediated dysphoria is thought to occur via $\kappa$-opioid receptor regulation of dopamine release in the nucleus accumbens (Spanagel et al., 1990; Pliakas et al., 2001).

Upregulation of the enkephalin neuropeptide system is also reported to produce antidepressant effects in the learned helplessness paradigm (Baamonde et al., 1992; Tejedor-Real et al., 1998). This suggests that inhibition of proenkephalin gene expression by mCREB would produce a depression-like phenotype and that CREB would produce an antidepressant-like effect, actions that are opposite to those observed in the current study. Why the predominant effect in the bitransgenic mice or in response to viral expression of mCREB is consistent with regulation of prodynorphin, and not proenkephalin, expression is not clear. One possibility is that, when both systems are regulated by CREB, the actions of prodynorphin override the actions of proenkephalin. Another likely possibility is that there are additional genes that are regulated by $\mathrm{CREB}$ and $\mathrm{MCREB}$ that also contribute to the behavioral phenotype.

The results of this study support the notion the mesolimbic 
dopamine system is involved in the etiology and treatment of depression and suggest that depression in general, or subtypes of this disorder, may be more responsive to antidepressant drugs that include efficacy for inhibition of the dopamine transporter. Moreover, the results indicate that another potential target for development of antidepressant medication is blockade of dynorphin- $\kappa$ opioid receptors. In addition, although the region-specific effects of CREB make it an unlikely candidate, it is possible that upstream elements in the cAMP-CREB cascade, such as isoforms of cAMP phosphodiesterases that are differentially expressed in the mesolimbic dopamine system versus other limbic brain structures, could be targeted for potential antidepressant drug development.

\section{REFERENCES}

Baamonde A, Dauge V, Ruiz-Gayo M, Fulga IG, Turcaud S, FournieZaluski M-C, Roques BP (1992) Antidepressant-type effects of endogenous enkephalins protected by systemic RB 101 are mediated by opioid $\delta$ and dopamine D1 receptor stimulation. Eur J Pharmacol 216:157-166

Blom J, Tascedda F, Carra S, Ferraguti C, Barden N, Brunello N (2002) Altered regulation of CREB by chronic antidepressant administration in the brain of transgenic mice with impaired glucocorticoid receptor function. Neuropsychopharmacology 26:605-614.

Borsok D, Konradi C, Falkowski O, Comb M, Hyman S (1994) Molecular mechanisms of stress-induced proenkephalin gen regulation: CREB interacts with the proenkephalin gene in the mouse hypothalamus and is phosphorylated in response to hyperosmolar stress. Mol Endocrinol 8:240-248.

Caldarone B, George TP, Zachariou V, Picciotto M (2000) Gender differences in learned helplessness behavior are influenced by genetic background. Pharmacol Biochem Behav 66:811-817.

Carlezon JW, Thome J, Olson V, Lane-Ladd SB, Brodkin ES, Hiroi N, Duman RS, Neve RL, Nestler EJ (1998) Regulation of cocaine reward by CREB. Science 282:2272-2275.

Chen A-H, Shirayama Y, Shin K-H, Neve RL, Duman RS (2001) Expression of the cAMP response element binding protein (CREB) in hippocampus produces antidepressant effect. Biol Psychiatry 49:753-762.

Chen J, Kelz MB, Zeng G, Sakai N, Steffen C, Shockett PD, Picciotto M, Lazova R, Duman RS, Nestler EJ (1998) Transgenic animal models for inducible, targeted gene expression in brain. Mol Pharmacol $54: 495-503$.

Cole R, Konradi C, Douglass J, Hyman SE (1995) Neuronal adaptation to amphetamine and dopamine: molecular mechanisms of prodynorphin gene regulation in rat striatum. Neuron 14:813-823.

Collins-Hicok J, Lin L, Spiro C, Laybourn PJ, Tschumper R, Rapacz B, McMurray CT (1994) Induction of the rat prodynorphin gene through Gs-coupled receptors may involve phosphorylation-dependent derepression and activation. Mol Cell Biol 14:2837-2848.

Conti A, Cryan JF, Dalvi A, Lucki L, Blendy JA (2002) CREB is essential for the upregulation of BDNF transcription, but not the behavioral or endocrine responses to antidepressant drugs. J Neurosci 3262-3268.

Curran E, Watson SJ (1995) Dopamine receptor mRNA expression patterns by opioid peptide cells in the nucleus accumbens of the rat: a double in situ hybridization study. J Comp Neurol 361:57-76.

Dowlatshahi D, MacQueen GM, Wang JF, Young LT (1998) Increased temporal cortex CREB concentrations and antidepressant treatment in major depression. Lancet 352:1754-1755.

Duman R, Heninger GR, Nestler EJ (1997) A molecular and cellular theory of depression. Arch Gen Psychiatry 54:597-606.

Duman R, Malberg J, Nakagawa S, D'Sa C (2000) Neuronal plasticity and survival in mood disorders. Biol Psychiatry 48:732-739.

Furth P, Onge LS, Böger H, Gruss P, Gossen M, Kistner A, Bujard H, Hennighausen L (1994) Temporal control of gene expression in transgenic mice by a tetracycline-responsive promoter. Proc Natl Acad Sci USA 91:9302-9306.

Gerfen C, Young WS (1988) Distribution of striatonigral and striatopallidal peptidergic neurons in both patch and matrix compartments: an in situ hybridization histochemistry and fluorescent retrograde tracing study. Brain Res 460:161-167.

Gonzalez GA, Montminy MR (1989) Cyclic AMP stimulates somatostatin gene transcription by phosphorylation of CREB at Serine 133. Cell 59:675-680.
Kelz M, Chen J, Carlezon WA, Whisler K, Gilden L, Beckmann AM, Steffen C, Zhang Y-J, Marotti L, Self DW, Tkatch T, Baranauskas T, Surmeier G, Neve RJ, Duman RS, Picciotto MR, Nestler EJ (1999) Expression of the transcription factor deltaFosB in the brain controls sensitivity to cocaine. Nature 401:272-276.

Manier D, Shelton RC, Sulser F (2002) Noradrenergic antidepressants: does chronic treatment increase or decrease nuclear CREB-P? J Neural Transm 109:91-99.

Manji H, Drevets WC, Charney DS (2001b) The cellular neurobiology of depression. Nat Med 7:541-547.

Milner B, Squire LR, Kandel ER (1998) Cognitive neuroscience and the study of memory. Neuron 20:445-468.

Nakagawa S, Kim J-E, Lee R, Malberg JE, Chen J, Steffen C, Zhang Y-J, Nestler EJ, Duman RS (2002) Regulation of neurogenesis in adult mouse hippocampus by cAMP and cAMP response element-binding protein. J Neurosci 22:3673-3682.

Nestler E, Aghajanian GK (1997) Molecular and cellular basis of addiction. Science 278:58-63.

Nestler EJ, Barrot M, DiLeone RJ, Eisch AJ, Gold SJ, Monteggia LM (2002) Neurobioloy of depression. Neuron 34:13-25.

Newton S, Dow A, Terwilliger R, Duman RS (2002) A simplified method for combined immunohistochemistry and in situ hybridization in fresh frozen, cryocut mouse brain sections. Brain Res Brain Res Protoc 9:214-219.

Nibuya M, Nestler EJ, Duman RS (1996) Chronic antidepressant administration increases the expression of cAMP response element binding protein (CREB) in rat hippocampus. J Neurosci 16:2365-2372.

Paxinos G, Watson C (1997) The rat brain in stereotaxic coordinates. New York: Academic.

Pliakas A, Carlson RR, Neve RL, Konradi C, Nestler EJ, Carlezon WA (2001) Altered responsiveness to cocaine and increased immobility in the forced swim test associated with elevated CREB expression in the nucleus accumbens. J Neurosci 21:7397-7403.

Rossby S, Manier DH, Liang S, Nalepa I, Sulser F (1999) Venlafaxine; pharmacological actions beyond aminergic receptors. Int J Neuropsychopharmacol 2:1-8.

Sakai N, Thome J, Chen J, Kelz M, Nestler EJ, Duman RS (2002) Inducible and brain-region specific expression of CREB. Mol Pharmacol 61:1453-1464.

Sambrook J, Fritsch EF, Maniatis T (1989) Molecular cloning: a laboratory manual. Cold Spring Harbor, NY: Cold Spring Harbor Laboratory.

Seligman M, Beagley G (1975) Learned helplessness in the rat. J Comp Physiol Psychol 88:534-541.

Shanks N, Anisman H (1989) Strain-specific effects of antidepressants on escape deficits induced by inescapable shock. Psychopharmacology 99:122-128.

Shaywitz A, Greenberg ME (1999) CREB: a stimulus-induced transcription factor activated by a diverse array of extracellular signals. Annu Rev Biochem 68:821-861.

Shirayama Y, Chen AC-H, Nakagawa S, Russell RS, Duman RS (2002) Brain derived neurotrophic factor produces antidepressant effects in behavioral models of depression. J Neurosci 22:3251-3261.

Shockett P, Difilippantonio M, Hellman N, Schatz DG (1995) A modified tetracycline-regulated system provides autoregulatory, inducible gene expression in cultured cells and transgenic mice. Proc Natl Acad Sci USA 92:6522-6526.

Silva A, Kogan JH, Frankland PW, Kida S (1998) CREB and memory. Annu Rev Neurosci 21:127-148.

Spanagel R, Shippenberg TS (1993) Modulation of morphine-induced sensitization by endogenous $\kappa$ opioid systems in the rat. Neurosci Lett 153:232-236.

Spanagel R, Herz A, Shippenberg TS (1990) The effects of opioid peptides on dopamine release in the nucleus accumbens: an in vivo microdialysis study. J Neurochem 55:1734-1740.

Tejedor-Real P, Mico JA, Smadja C, Maldonado R, Roques BP, GibertRahola (1998) Involvement of $\delta$-opioid receptors in the effects induced by endogenous enkephalins on learned helplessness model. Eur J Pharmacol 354:1-7.

Thiébot M-H, Martin P, Puech AJ (1992) Animal behavioural studies in the evaluation of antidepressant drugs. Br J Psychiatry Suppl 160:44-50.

Thome J, Sakai N, Shin KH, Steffen C, Zhang Y-J, Impey S, Storm DR, Duman RS (2000) cAMP response element-mediated gene transcription is upregulated by chronic antidepressant treatment. J Neurosci 20:4030-4036.

Willner P (1984) The validity of animal models of depression. Psychopharmacology 83:1-16. 